\title{
Agroclimatic zoning for coffee crop in Angola ${ }^{1}$
}

\author{
Aristides Osvaldo $\mathrm{Ngolo}^{2}$, Elpídio Inácio Fernandes Filho², \\ Williams Pinto Marques Ferreira ${ }^{3}$, Raphael Bragança Alves Fernandes ${ }^{2}$
}

\section{ABSTRACT}

The Angolan Government intends to recover its 1970s expressive production of coffee by means of agricultural financing programs, mainly directed to family farmers. This study aimed to perform the agroclimatic zoning for the coffee crop in the Angolan territory. Data or estimates of annual temperature, effective and total rainfall rates, climatic water balance and annual water deficit were evaluated for all the 163 Angolan municipalities. The effective and total precipitation data were used for the agroclimatic zoning of the coffee crop in the country. Based on the effective precipitation data, $1 \%, 20 \%$ and $79 \%$ of the Angolan territory were respectively considered suitable, marginal and unsuitable for the Arabica coffee, while, for the Robusta coffee, the same rates were, respectively, $1 \%, 8 \%$ and $91 \%$. Based on the total precipitation data, these rates were $2 \%, 27.5 \%$ and $70.5 \%$ for the Arabica coffee and $1 \%, 11.8 \%$ and $87.2 \%$ for the Robusta coffee. The areas considered marginal and unsuitable for the coffee crop in Angola are related to water deficit conditions, mainly in the southwestern region and along the coastal strip. The results obtained from the climatic water balance show that most part of the Angolan territory is marginal or unsuitable for the coffee crop.

KEY-WORDS: Coffea arabica; Coffea canephora; climatic water balance.

\section{INTRODUCTION}

Coffee is the second most valuable commodity in the world, and it is a key product in the global economy, often surpassed only by oil, as a source of foreign exchange in developing countries (ICO 2014).

The coffee production was relevant until Angola became independent from Portugal, in 1975. A study conducted at the end of the year 2000 by the Instituto Nacional do Café de Angola (Inca) and

\section{RESUMO}

\section{Zoneamento agroclimático \\ para a cultura do cafeeiro em Angola}

O Governo de Angola tem a intenção de recuperar sua alta produção de café da década de 1970, por meio de programas de financiamento agrícola direcionados especialmente aos agricultores familiares. Objetivou-se realizar o zoneamento agroclimático para a cultura do cafeeiro em território angolano. Dados ou estimativas de temperatura anual, precipitação efetiva e total, balanço hídrico climático e déficit de água anual foram avaliados para todos os 163 municípios angolanos. Os dados de precipitação efetiva e total foram utilizados para o zoneamento agroclimático da cultura do cafeeiro no país. Com o uso da precipitação efetiva, $1 \%, 20 \%$ e $79 \%$ do território de Angola foram considerados adequado, marginal e inapto para o café Arábica, respectivamente, enquanto, para o café Robusta, esses mesmos percentuais foram de $1 \%, 8$ \% e $91 \%$. Com a utilização da precipitação total, esses mesmos valores foram de $2 \%, 27,5 \%$ e $70,5 \%$ para o café Arábica e $1 \%, 11,8 \%$ e 87,2 \% para o Robusta. As áreas marginais e inaptas para a produção de café em Angola estão associadas às condições de déficit hídrico, principalmente na região sudoeste do país e ao longo da faixa costeira. Os resultados obtidos a partir do balanço hídrico climático indicam que a maior parte do território angolano é marginal ou inapta para a cultura do cafeeiro.

PALAVRAS-CHAVE: Coffea arabica; Coffea canefora; balanço hídrico climático.

Centro de Investigação das Ferrugens do Cafeeiro (CIFC) diagnosed low coffee yields in Angola caused by the plants advanced age and less resistance to pests and diseases (Costa Neto et al. 2008).

Over the last few years, the Inca has carried out official plans and programs aiming to recover the coffee production in Angola by increasing the cultivated areas and enhancing the quality of the harvested fruits (Inca 2013).

Despite the low yields in Angola, António (2008) reported that the Arabica coffee has been

1. Manuscript received in Nov./2017 and accepted for publication in Jan./2018 (http://dx.doi.org/10.1590/1983-40632018v4850109).

2. Universidade Federal de Viçosa, Departamento de Solos, Viçosa, MG, Brasil.E-mails: aristidesosvaldo@hotmail.com, elpidio.solos@gmail.com,raphael@ufv.br.

3. Empresa Brasileira de Pesquisa Agropecuária (Embrapa Café), Viçosa, MG, Brasil. E-mail: williams.ferreira@embrapa.br. 
grown on the plateau and sub-plateau regions in the provinces of Huambo, Bie, Huila and Benguela. These provinces are coincident with the major potential of the Arabica coffee production, according to topoclimatic aspects (Diniz 1973).

Climate elements are extremely important for the coffee crop. There are two well-differentiated seasons in Angola: a rainy, humid and hot season from September to April, and a dry season from May to August (Angola 2004).

Relief aspects are also relevant to the coffee crop. The relief of Angola presents a massive upland and a narrow strip, with altitudes from the sea level to $200 \mathrm{~m}$ above the sea level (Angola 2006). The topography is also made up of "stairs", consisting of plateaus and mountains of 1,200-1,600 m and favorable temperature conditions for the cultivation of the Arabica coffee (Coffea arabica). Varieties of the Robusta coffee (Coffea canephora) species may be found in the Angolan tropical forest regions, even above 1,300 $\mathrm{m}$ (Carvalho 1946), concentrated in latitudes near the Equator, such as in the northwestern region of the country, especially in the Uíge province.

In view of the diversity of altitude classes, a wide variety of soil types is found in Angola. The majority of them are highly weathered soils, named Oxisols. Those soils are mainly used for agriculture and are characterized by low $\mathrm{pH}$, high contents of iron and aluminum oxides, and low nutrient contents. On the other hand, Oxisols present a good drainage and growth-favorable physical properties, as well as a good response to fertilizers (Gonçalves Júnior et al. 2007).

Due to the influence of the altitude factor in the regions of origin of the Arabica coffee, the ideal climate for this crop is mild and humid, with the occurrence of a dry season ranging from two to four months (Reis 2010). The Arabica coffee is a typical tropical species occupying mountainous areas, commonly grown at 1,000-2,000 $\mathrm{m}$ above the sea level, whereas the Robusta coffee is most adapted to low altitudes in equatorial regions (Matiello 1991). The temperature for the adequate growth and development of the Arabica coffee is $18-21^{\circ} \mathrm{C}$, while the suitable accumulated rainfall for the crop is $1,200-1,500 \mathrm{~mm}$, distributed throughout nine to ten months of the year (António 2008).

The center of origin of the Robusta coffee species is characterized by low altitudes, annual temperatures around $26{ }^{\circ} \mathrm{C}$ and annual rainfall of 1,500-2,000 mm (Coste 1992). The Robusta coffee is adapted to hotter climates, when compared to the Arabica coffee, and requires mean annual temperatures of $22-27^{\circ} \mathrm{C}$ (António 2008), which limit its cultivation in the highland regions of Angola. The Angolan territory supports the coffee crop because there is usually a rainy period of nine months and a dry period of three months, which contribute to a good growth and promote a uniform flowering and a more concentrated harvest, respectively.

Regional rainfall and temperature are essential for the adequate development of coffee plants. The vegetative growth rate (growth of orthotropic and reproductive branches, node formation, leaf expansion, etc.) of coffee varies regionally owing to the occurrence of different climate conditions, especially concerning air temperature and rainfall and photoperiod rates (Ronchi \& DaMatta 2007).

Changes in climate conditions may influence the coffee physiology by promoting, for instance, the transition from the vegetative to the reproductive phase (Pohlan \& Janssens 2010). In view of that, more knowledge is required about water balance and the dynamics of air temperature in regions of coffee production. Currently, a tool widely used for assessing the risk management in agriculture, aiming to ensure a successful production under diverse weather conditions, is agroclimatic zoning. This approach is already being applied to the coffee crop by the Empresa Brasileira de Pesquisa Agropecuária (Embrapa).

By using agroclimatic zoning, it is possible to identify areas suitable for a given crop considering climatic aspects. The approach is based on geotechnologies (or GIS), which consist of a set of procedures, techniques and products for the collection and processing of spatial information (Bacani \& Luchiari 2014). With fewer requirements of field surveys and laboratory analyses, GIS may be used to characterize the physical environment of a given region at a higher speed and with a lower cost. In addition, GIS have been widely used for their easiness of operation and capacity of application to many regions of the world.

Considering the investments of the Angolan Ministry of Agriculture toward the recovery of their coffee production, the establishment of agroclimatic zoning for the coffee crop thereof plays an important role in the identification of new areas with potential for coffee cultivation, thus facilitating the resumption of the coffee production in the country. Due to lack of information, and considering the importance 
of these data for policymakers decision-making aimed at increasing the chances of success of the re-establishment of the coffee production in Angola, this study aimed to perform agroclimatic zoning for the coffee crop in the Angolan territory.

\section{MATERIAL AND METHODS}

The studied area was the Republic of Angola, located in the African continent, between the latitudes $4^{\circ} 22^{\prime} \mathrm{S}$ and $18^{\circ} 02^{\prime} \mathrm{S}$ and longitudes $11^{\circ} 41^{\prime} \mathrm{E}$ and $24^{\circ} 05^{\prime}$ E. Angola occupies an area of $1,246,700 \mathrm{~km}^{2}$ and has 18 provinces. The topography is flat along the coastal strip, but, from the sea, the altitude increases significantly up to the center of the country, where the relief is flatter again. Angola presents Aw, Cwa, Cwb, BSh and BWh climate, according to the Köppen climate classification (Peel et al. 2007).

The grid climate data corresponding to the 1960-1990 period were obtained from the WorldClim Global Climate Data, version 1.0 (Hijmans et al. 2005), a database that provides historical series of 50 years (1950-2000). The data were previously tested for their quality and consistency and compiled for all the Angolan territory from layers (gridded climate data) with a spatial resolution of approximately $1 \mathrm{~km}^{2}$ (Figure 1). Each municipality was assigned in a polygon. Using the Zonal Statistics as Table, an ArcMap $^{\circledR}$ tool, data of mean temperatures and total monthly rainfall were extracted from the center points of the polygons (each polygon represents each municipality of Angola). Climate data of neighboring regions in other countries were obtained from the World Meteorological Organization website (WMO 2014), considering an average observation period of 30 years (1961-1990).

Using the Raster Calculator tool of the $\operatorname{ArcMap}^{\circledR}$, the mean annual temperature was calculated from the monthly temperature means, and a mean annual air temperature map of the Angolan territory was built. Subsequently, and considering thermal requirements of the Arabica and Robusta coffees, the temperature map was reclassified to obtain a new map of suitable areas for the coffee crop with homogeneous temperatures. Finally, the temperature and rainfall data were used to calculate the climatic water balance.

A digital elevation model (Figure 2a) was obtained from twenty scenes acquired by the Shuttle Radar Topography Mission (SRTM), covering the entire territory of Angola. The data were downloaded from the SRTM 90 m Digital Elevation Data (Farr \& Kobrick 2000, Van Zyl 2001). The GIS software ArcMap $^{\circledR} 10.1$ was used to build the digital elevation model and the annual water deficit map of the Angolan territory.

Effective rainfall was calculated using the CropWat software, version 8.0 (FAO 2015). This software allows calculating the water and irrigation demands of crops and uses the method proposed by the USDA to estimate the effective rainfall based on climatic water balance data. Following this method, the effective rainfall was estimated by the following equations:

$$
\begin{aligned}
& P_{\text {eff }}=\frac{P_{\text {tot }} \times\left(125-0.2 P_{\text {tot }}\right)}{12} \text {, when } P_{\text {tot }}<250 \mathrm{~mm} ; \\
& P_{\text {eff }}=125+0.1 \mathrm{P}_{\text {tot' }} \text { when } P_{\text {tot }}>250 \mathrm{~mm},
\end{aligned}
$$
where $\mathrm{P}_{\text {eff }}$ is the effective rainfall $(\mathrm{mm})$ and $\mathrm{P}_{\text {tot }}$ the total rainfall $(\mathrm{mm})$.

The soil water deficit was estimated based on climatic water balance data, considering the

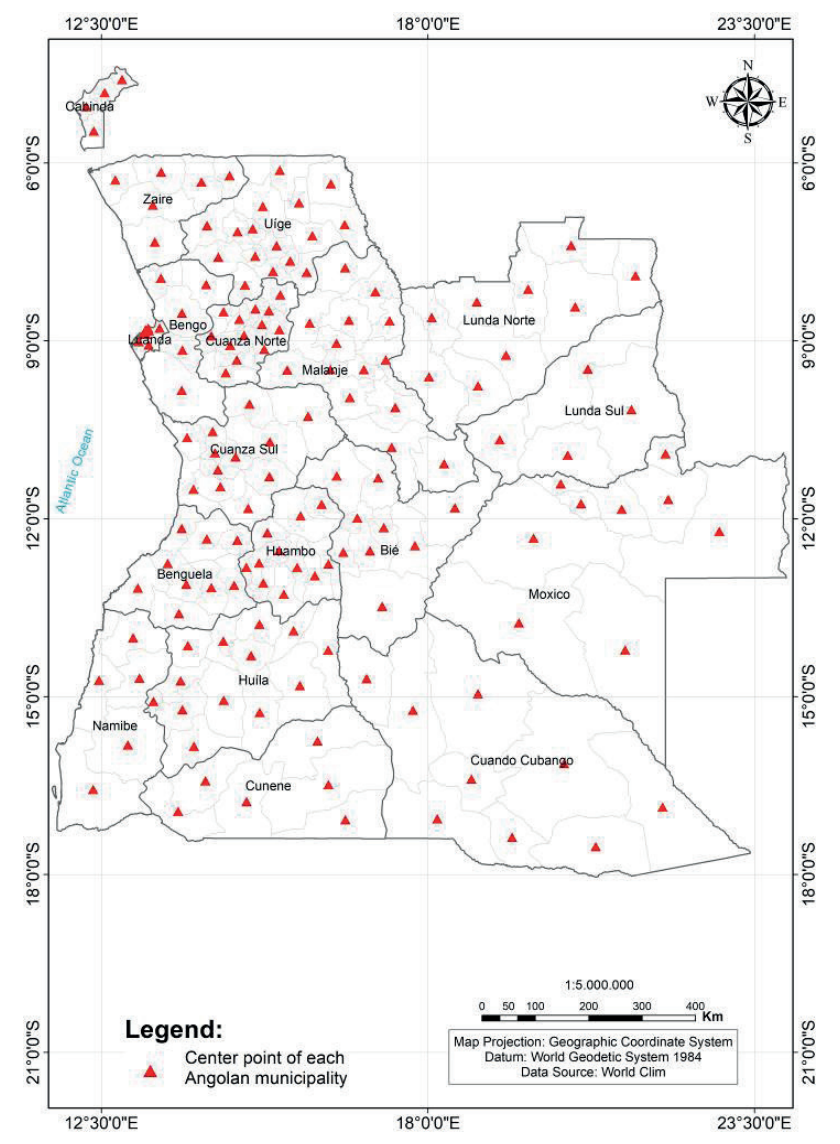

Figure 1. Municipalities of Angola and neighboring regions. 

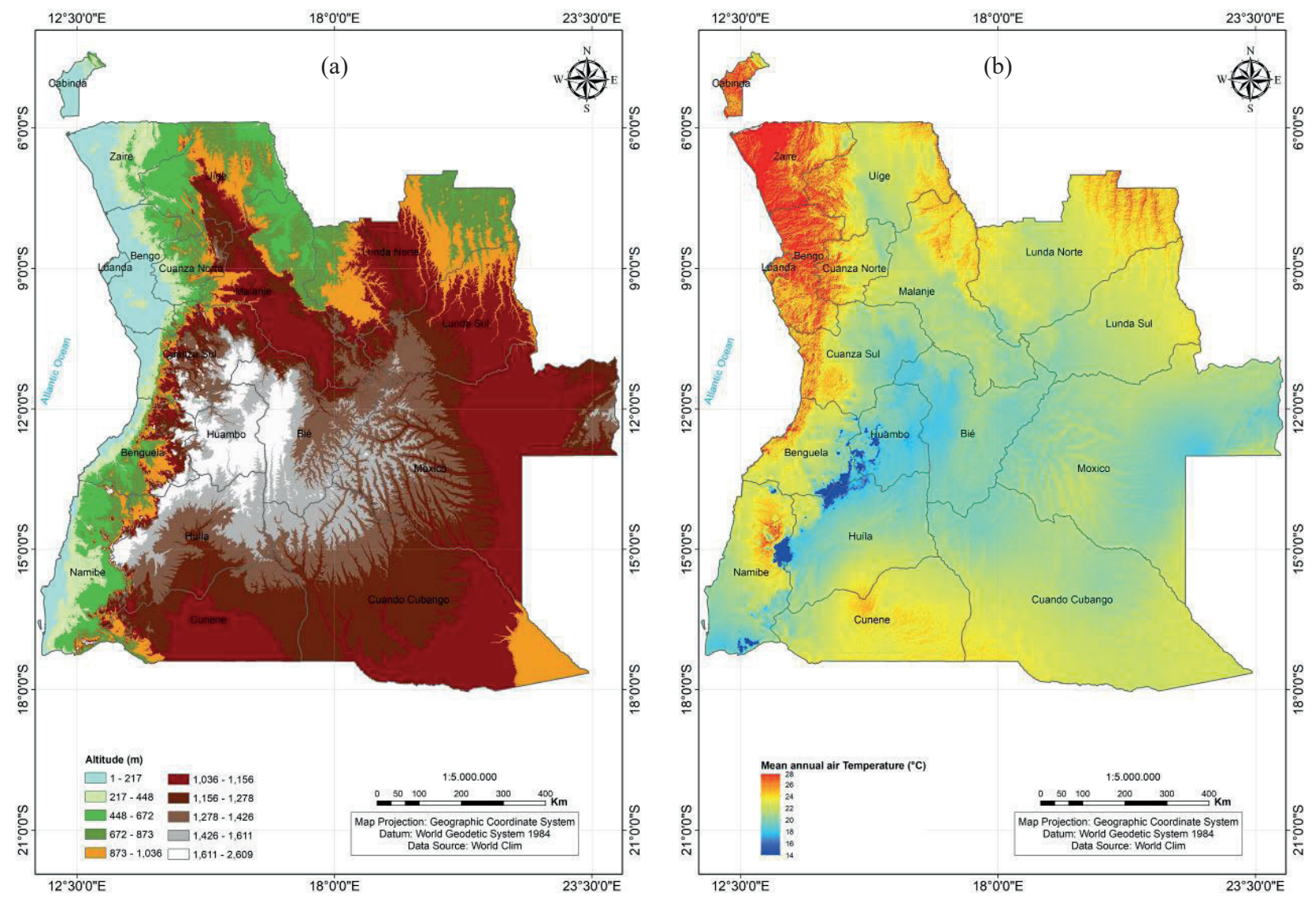

Figure 2. Digital elevation model (a) and mean annual air temperature (b) for Angola.

total available water. This parameter depends on the effective root depth and on some soil physical properties, such as bulk density, field capacity and permanent wilting point (Vianello \& Alves 2012). In the present study, the total available water was defined by: TAW $=1,000\left(\theta_{\mathrm{FC}}-\theta_{\mathrm{PWP}}\right) \times Z_{\mathrm{r}}$, where: TAW is the total available soil water $(\mathrm{mm}) ; \theta_{\mathrm{FC}}$ the soil moisture at field capacity $\left(\mathrm{m}^{3} \mathrm{~m}^{-3}\right) ; \theta_{\mathrm{PWP}}$ the soil moisture at the permanent wilting point $\left(\mathrm{m}^{3} \mathrm{~m}^{-3}\right)$; and $\mathrm{Z}_{\mathrm{r}}$ the effective root depth (m).

Due to the lack of data on representative soils from Angola, the calculation of the total available soil water was first tested considering the extreme values (minimum and maximum) of $\theta_{\mathrm{FC}}$ and $\theta_{\mathrm{PWP}}$, as proposed by Allen et al. (1998) for coarse-, medium- and fine-textured soils. Based on those values and considering $1.2 \mathrm{~m}$ of effective root depth (the same authors consider coffee root varying 0.9$1.5 \mathrm{~m})$, the estimated total available water values were 45-165 mm for sandy soils, 144-210 mm for loamy soils and 108-240 mm for clayed soils. Based on those estimates, we prefer to consider
$125 \mathrm{~mm}$ as a general total available water value, as recommended by Sediyama et al. (2001), since this is a representative value of this parameter for Brazilian soils where coffee is grown. This decision is supported by the similarity between the Brazilian and Angolan Latosols, soil order where coffee is predominant in both countries.

The annual climatic water balance was then calculated using a spreadsheet for all the Angolan municipalities and for other 10 adjacent regions abroad. Interpolators (simple kriging, cokriging and IDW) were evaluated for climatic water balance, considering effective and total rainfall data. The simple kriging method was chosen as the best statistical tool to perform this study. After this procedure, thematic maps ( $90 \mathrm{~m}$ of spatial resolution) of thermal suitability and annual water deficit were built, considering criteria defined by different authors (Table 1). Those criteria allow classifying the areas, considering thermal conditions as suitable, unsuitable due to high temperatures, unsuitable due to low temperatures, marginal, marginal due to high temperatures, marginal 
Table 1. Classification of areas considering thermal conditions and water deficit for the Arabica and Robusta coffee crops.

\begin{tabular}{lcccc}
\hline \multirow{2}{*}{ Suitability classes } & \multicolumn{2}{c}{ Temperature ${ }^{(1)}$} & \multicolumn{2}{c}{ Water stress $^{(2)}$} \\
\cline { 2 - 4 } & Arabica coffee & Robusta coffee & Arabica coffee & Robusta coffee \\
\cline { 2 - 4 } & \multicolumn{2}{c}{${ }^{\circ} \mathrm{C}$} & - & - \\
\hline Unsuitable due to low temperatures & $<17$ & $<21$ & - \\
Marginal due to low temperatures & $17-18$ & $21-22$ & - \\
Suitable & $18-23$ & $22-26$ & $<150$ & $<150$ \\
Marginal & - & - & $150-200$ & $150-200$ \\
Marginal due to high temperatures & $23-24$ & $26-28$ & - & - \\
Unsuitable due to high temperatures & $>24$ & $>28$ & - & $>200$ \\
Unsuitable & - & - & 200 & - \\
${ }^{(1)}$ Mean annual temperature; ${ }^{(2)}$ annual water deficit. Based on Pereira et al. (2008), Pohlan \& Janssens (2010) and Luppi et al. (2014). &
\end{tabular}

due to low temperatures and unsuitable. Maps of annual water deficit were built considering effective and total rainfall data, and Angolan areas were categorized as belonging to the suitable, unsuitable and marginal classes for the coffee crop.

\section{RESULTS AND DISCUSSION}

Climate historical series (1950-2000) show an Angolan annual rainfall of $1,018.72 \mathrm{~mm}$ and annual mean temperature of $22^{\circ} \mathrm{C}$. March, in late summer, is the rainiest month in Angola, while June to August is the driest period. There is not a great variation in temperatures in the Angolan territory. Throughout the year, the thermal amplitude between the coldest month (July) and the hottest months (March, April and September) is $4^{\circ} \mathrm{C}$. These climate conditions are adequate for coffee production, but the crop cannot be adopted throughout the entire country.

The annual average temperatures in Angola have complied with the change of altitude (Figure 2b), where the lowest temperatures associated with the Arabica coffee cultivation are found in the highest regions of the country (over 1,000 m), with temperatures around $19{ }^{\circ} \mathrm{C}$. Higher temperature values (above $24^{\circ} \mathrm{C}$ ) are found in low-altitude regions (below $400 \mathrm{~m}$ ) near the coast, in the northwestern region of the country. In this low-altitude region, and in proximity to the Equator, average monthly temperatures vary less throughout the year, favoring the cultivation of the Robusta coffee.

Most part of the Angolan territory would be considered adequate for the Arabica coffee if only thermal conditions were evaluated (Figure 3a). Suitable areas for coffee production may be related to milder temperatures typical of the highlands region in the central, southern and eastern parts of the country, where a relief above $1,000 \mathrm{~m}$ predominates. Based solely on thermal suitability, $82.4 \%\left(996,071 \mathrm{~km}^{2}\right)$ of the Angolan territory were classified as adequate for the Arabica coffee. Marginal and unsuitable areas due to high temperatures represent $8.3 \%$ and $8.9 \%$ of the country, respectively. Marginal and unsuitable areas due to low temperatures, which are related to annual mean temperatures below $18^{\circ} \mathrm{C}$ and $17^{\circ} \mathrm{C}$, respectively, are not expressive, representing approximately $0.4 \%$ of Angola.

Restricted areas due to high temperatures are located in lowlands close to the coast and in the northwestern part of Angola. Two other depressions located in the north and northeast are included in the restricted areas, due to their high temperatures for the Arabica coffee.

Regions with mean temperatures below $17^{\circ} \mathrm{C}$, considered unsuitable due to cold conditions, represent less than $1 \%$ of the Angolan territory, indicating that the occurrence of frost is not a problem to the Arabica coffee cultivation. These areas include the highest areas of Angola, with altitudes over 2,000 m.

Concerning the thermal suitability for the Robusta coffee (Figure 3b), the plateau regions of Angola are unsuitable for growth, considering the recommended temperatures by Ferrão et al. (2007) and Matiello (1991), who indicated the best crop performance in hot and humid regions, at low altitudes. The regions deemed suitable for the Robusta coffee, considering temperature criteria, represent $34.4 \%\left(416,221 \mathrm{~km}^{2}\right)$ of Angola. Marginal areas due to cold conditions correspond to $25 \%$ of the country, while marginal areas due to high temperatures represent $1 \%$ of the territory. Unsuitable areas due to cold conditions cover a large portion of the country corresponding to $302,034 \mathrm{~km}^{2}$ $(39.6 \%)$. 

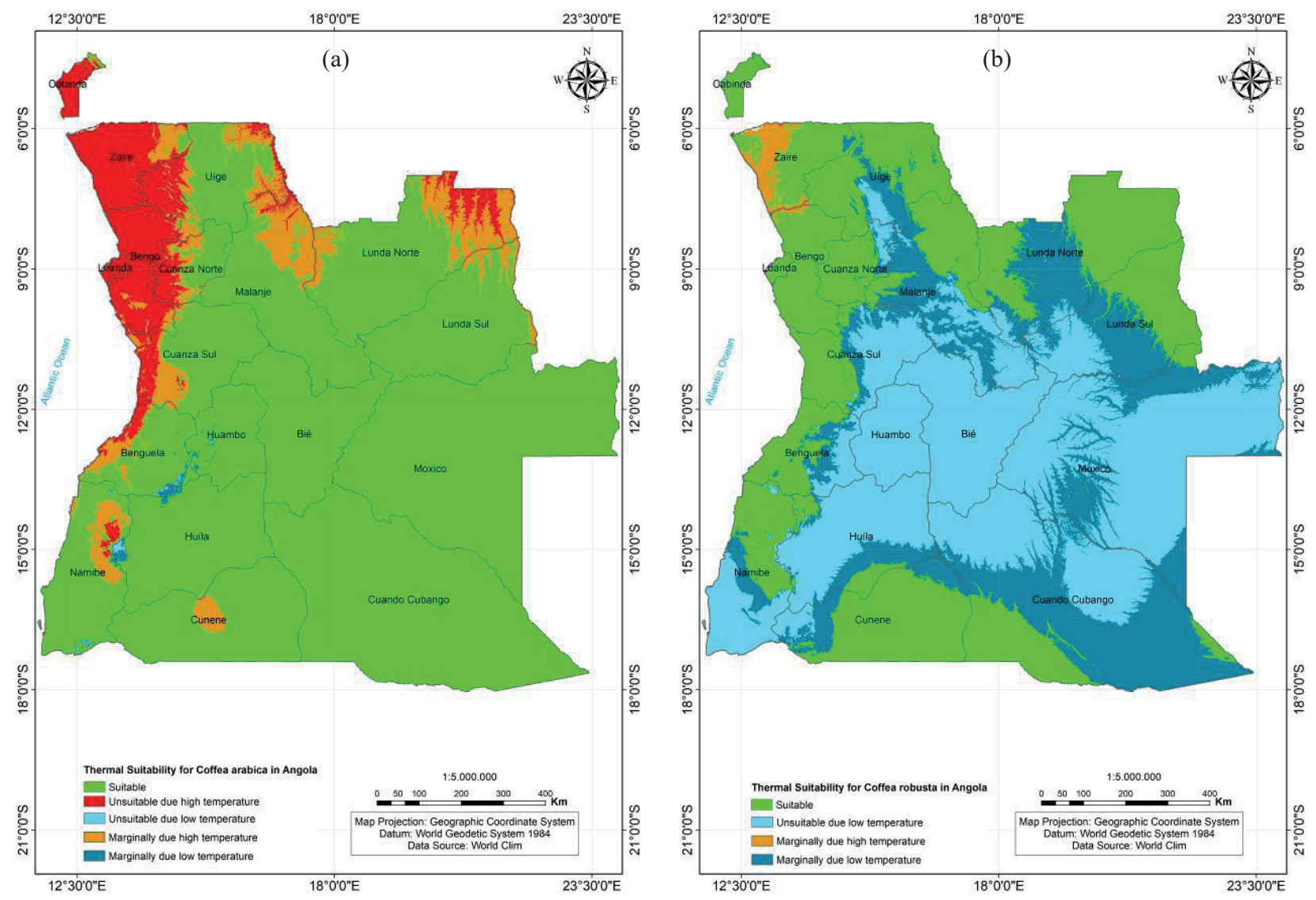

Figure 3. Thermal suitability for the Arabica (a) and Robusta (b) coffees in Angola.

Based on the climatic water balance results computed from the effective (Figure 4a) and total (Figure $4 \mathrm{~b}$ ) rainfall data, the annual water deficit maps were produced considering $150 \mathrm{~mm}$ as a threshold value for adequate water availability to the Arabica and Robusta coffees. Most part of Angola was identified as unsuitable for the coffee crop, based on climatic water balance, considering both the effective and total rainfall data. Marginal areas concentrate in the central and northern parts of Angola, coinciding with the highlands. Only a small area of the country was regarded as suitable for coffee production.

Based on the suitability maps of thermal conditions and annual water deficit, the agroclimatic zoning for the coffee crop in Angola was carried out considering both the effective and total rainfall data. Most part of the territory was classified as unsuitable for coffee, considering both variables linked to rainfall data, mainly for the Robusta coffee (Table 2).

Marginal areas for the Arabica coffee cultivation were found in the central region of the country, including the Huambo province, the east side of Cuanza Sul, the west side of Bie and the southern part of Malanje. In the north, a great part of the Uíge and Lunda Norte provinces was also included in the marginal areas (Figure 5a). A suitable area was located in a small area in the northwest of the Lunda Norte province.

Areas considered marginal for the Robusta coffee have reduced in the central part of Angola and changed to unsuitable, with marginal areas remaining in part of the Uíge and Lunda Norte provinces (Figure $5 b$ ). The high altitudes of the central part of Angola may explain the reduction of marginal areas for the Robusta coffee. The same region identified as suitable for the Arabica coffee cultivation in northwestern Lunda Norte was also classified as suitable for the Robusta coffee.

Since almost all $(98 \%)$ of the coffee producers in Angola are family farmers (Inca 2013), the areas classified as marginal may be a great challenge for crops, because the adoption of a supplementary irrigation system is required to boost the coffee production. 

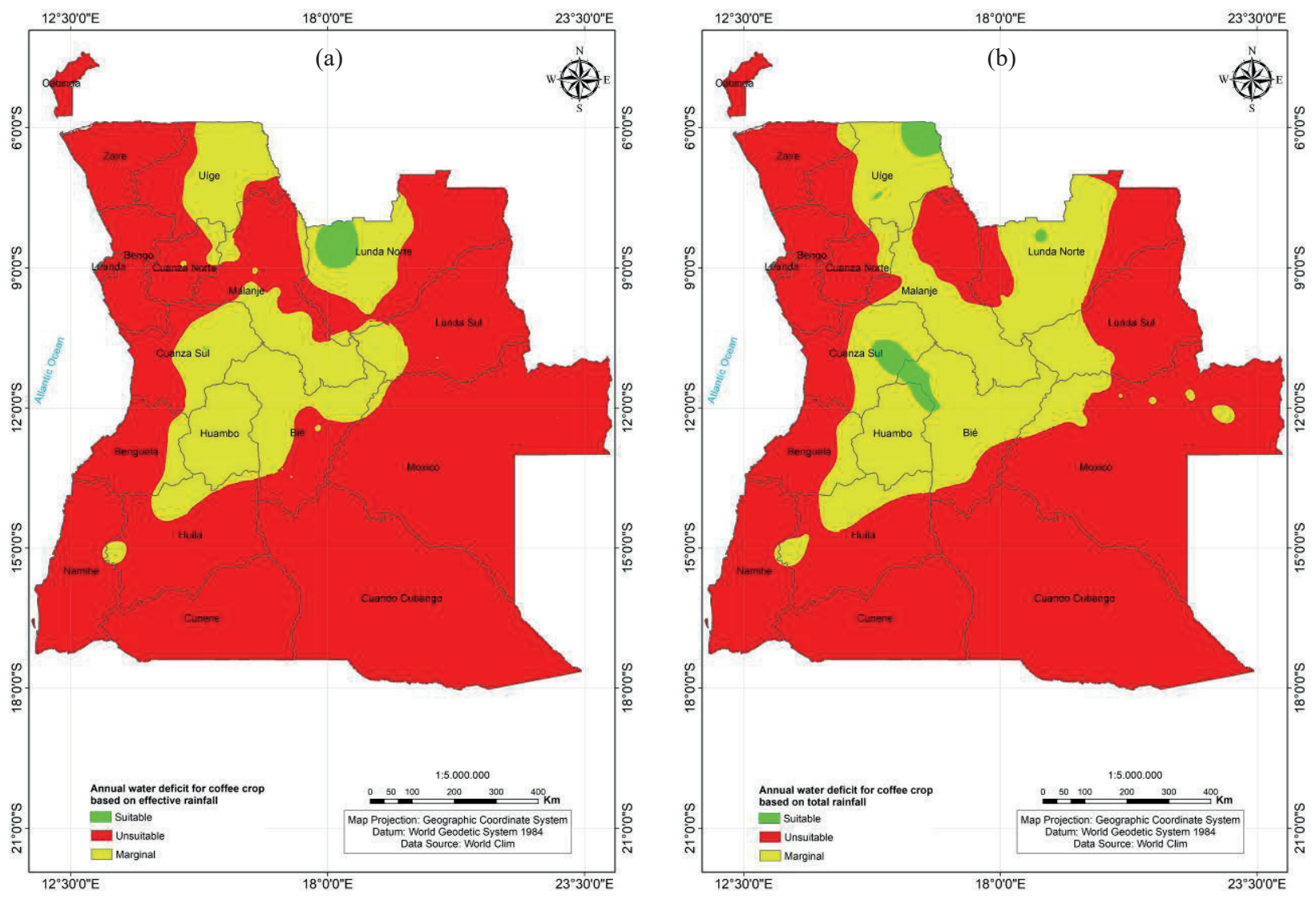

Figure 4. Annual water deficit suitability ( $\mathrm{mm}$ ) for the Arabica and Robusta coffees in Angola, considering the effective rainfall (a) and total rainfall (b) data.

Table 2. Agroclimatic zoning in Angola for the Arabica and Robusta coffees, based on effective and total rainfall data.

\begin{tabular}{|c|c|c|c|c|}
\hline \multirow{2}{*}{ Suitability } & \multicolumn{2}{|c|}{ Arabica coffee } & \multicolumn{2}{|c|}{ Robusta coffee } \\
\hline & $\mathrm{km}^{2}-$ & $\%$ & $\mathrm{~km}^{2}$ & $\%$ \\
\hline \multicolumn{5}{|c|}{ Based on effective rainfall data } \\
\hline Unsuitable & $955,722.33$ & 79.02 & $1,102,758.05$ & 91.18 \\
\hline Suitable & $6,966.07$ & 0.58 & $6,412.39$ & 0.52 \\
\hline Marginal & $246,676.36$ & 20.40 & $100,194.32$ & 8.30 \\
\hline Total & $1,209,364.76$ & 100.00 & $1,209,364.76$ & 100.00 \\
\hline \multicolumn{5}{|c|}{ Based on total rainfall data } \\
\hline Unsuitable & $863,401.70$ & 71.40 & $1,061,576.24$ & 87.79 \\
\hline Suitable & $12,710.96$ & 1.05 & $5,933.12$ & 0.49 \\
\hline Marginal & $333,252.10$ & 27.55 & $141,855.40$ & 11.72 \\
\hline Total & $1,209,364.76$ & 100.00 & $1,209,364.76$ & 100.00 \\
\hline
\end{tabular}

The agroclimatic zoning based on effective rainfall indicated more suitable and marginal areas for the Arabica coffee, in comparison with the Robusta coffee (Table 2). In addition, the potential areas without any water and thermal restriction encompassed $6,966 \mathrm{~km}^{2}$ for the Arabica coffee and $6,412 \mathrm{~km}^{2}$ for the Robusta coffee.
In view of these results, investments in irrigation and shading techniques may be considered interesting practices toward the improvement of coffee yields.

The agroclimatic zoning based on total rainfall (Figure 6) showed a reduction in unsuitable areas, in comparison with the zoning based on effective 

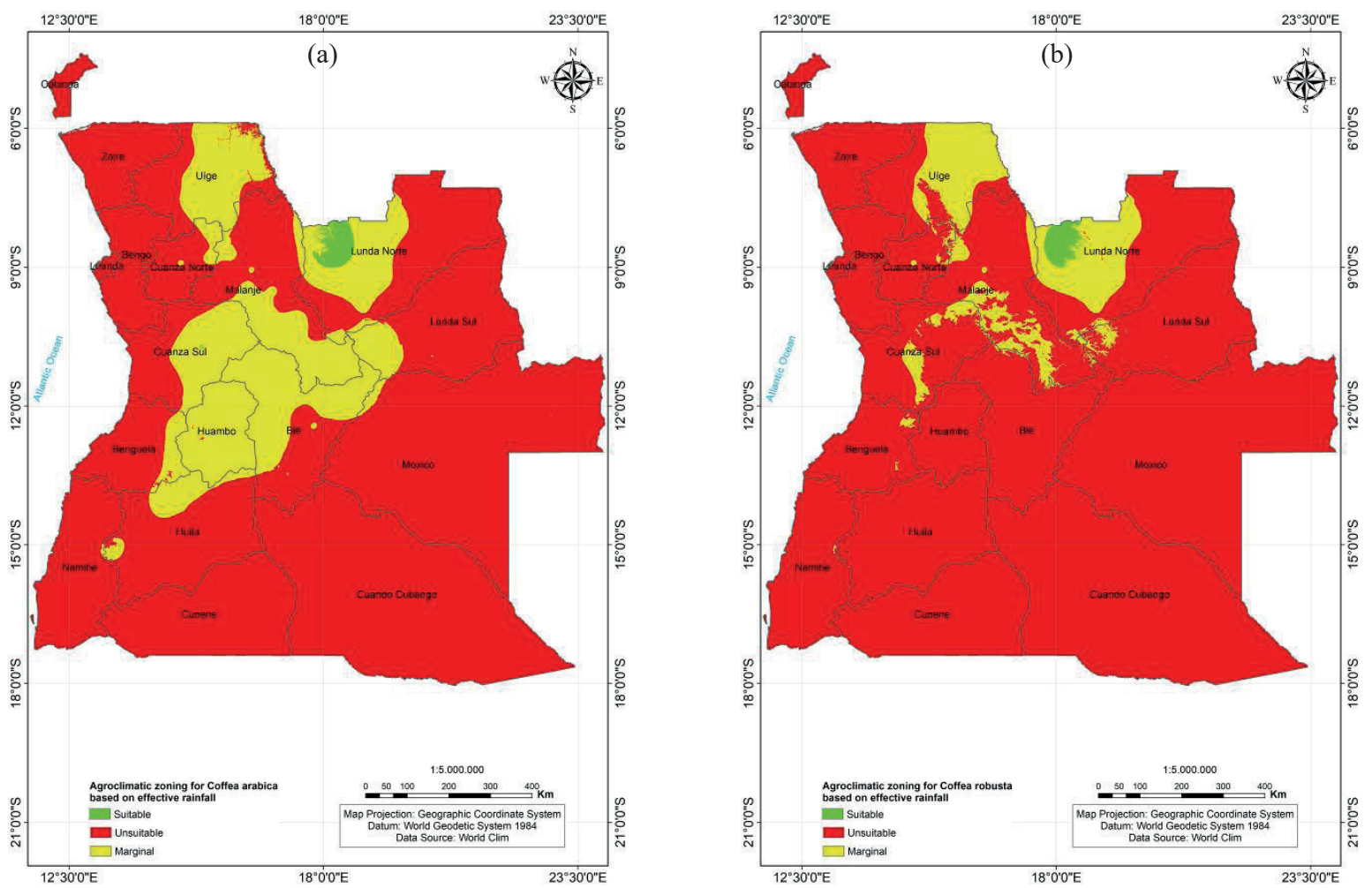

Figure 5. Agroclimatic zoning for the Arabica (a) and Robusta (b) coffees in Angola, based on thermal suitability maps and annual water deficit, considering the effective rainfall data.
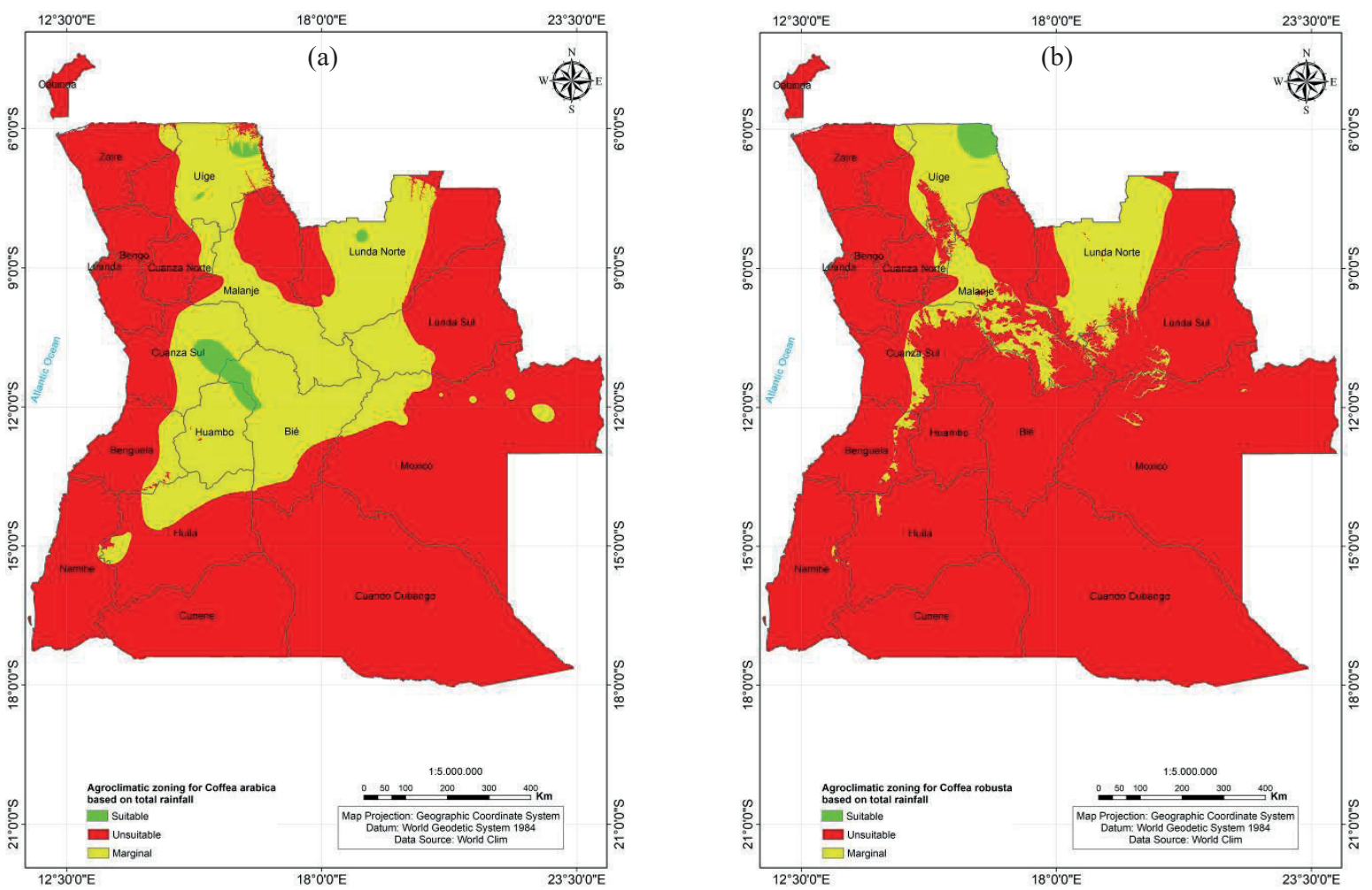

Figure 6. Agroclimatic zoning for the Arabica (a) and Robusta (b) coffees in Angola, based on thermal suitability maps and annual water deficit, considering the total rainfall data. 
rainfall (Figure 5). The zoning map for the Arabica coffee (Figure 6a) indicates suitable areas at higher altitudes in the center of the country, particularly in the provinces of Cuanza Sul, Bié and Huambo. Other three small suitable areas were indicated in Lunda Norte and Uíge. Suitable areas for the Robusta coffee were identified only in Uíge, where the altitude is $400-800 \mathrm{~m}$ and mean annual temperatures vary between $25.5^{\circ} \mathrm{C}$ and $28^{\circ} \mathrm{C}$.

Marginal areas for the Arabica coffee cultivation were identified in the center and north of Angola. For the Robusta coffee, this area was reduced and concentrated in most part of Lunda Norte and Uíge, in the western part of Malanje and in the central part of Kwanza Sul.

According to Odur (2005), the current coffee production in Angola is mainly focused on the Robusta coffee, but, in terms of potential, the present study showed more suitable areas for the Arabica coffee production, which are located in the central highlands (Kwanza-Sul, Huambo and Bié), where the climate and soil conditions support the vigorous development of the coffee crop.

One decade before, the estimated area for coffee production in Angola was 100,000 ha (Odur 2005), which is less than the sum of the total areas identified in this study as suitable for the Arabica and Robusta coffees (Table 2). This is an indicator of the potential to increase the coffee production in Angola, and agroclimatic zoning may be used as a tool to orient public policies and stakeholders in decision making.

Further studies are required to improve the agroclimatic zoning in Angola, for example, using field data on soil physical properties to perform better estimations of water deficit. Additionally, the weather stations network should be expanded around the country, in order to improve the performance on climate data modeling.

The suitable areas for the Arabica and Robusta coffees obtained in this study coincided with the main production regions previously identified by Diniz (1973), who reported crops restricted to low and warm regions of the Uíge province and part of Cuanza Sul and Cuanza Norte.

\section{CONCLUSIONS}

1. Any plans and programs aiming at enhancing the coffee sector in Angola should take into account the fact that most part of the Angolan territory is marginal or unsuitable for coffee production, in terms of climatic water balance;

2. Marginal areas are mostly limited by water deficit, which is most pronounced in the southwestern regions of the country and along the coastal strip, where high evapotranspiration rates determine a semi-arid climate.

\section{ACKNOWLEDGMENTS}

The authors would like to thank the Coordenação de Aperfeiçoamento de Pessoal de Nível Superior (Capes) and Conselho Nacional de Desenvolvimento Científico e Tecnológico (CNPq).

\section{REFERENCES}

ALLEN, R. G. et al. Crop evapotranspiration: guidelines for computing crop requirements. Rome: FAO, 1998. (Irrigation and drainage paper, 56).

ANGOLA. Ministério da Agricultura e Desenvolvimento Rural. Revisão do sector agrário e da estratégia de segurança alimentar para definição de prioridades de investimentos. Luanda: Ministério da Agricultura e Desenvolvimento Rural, 2004.

ANGOLA. Ministério do Urbanismo e Ambiente. Relatório do estado geral do ambiente em Angola. 2006. Available at: $<$ http://www2.ecolex.org/server2.php/libcat/ docs/LI/MON-083704.pdf>. Access on: 18 Mar. 2016.

ANTÓNIO, J. O microcrédito como ferramenta para o relançamento da cultura do café na região agrícola do Libolo e Amboim (Angola). 2008. 111 f. Dissertação (Mestrado em Economia Agrária e Sociologia Rural) Instituto Superior de Agronomia, Lisboa, 2008.

BACANI, V. M.; LUCHIARI, A. Geoprocessamento aplicado ao zoneamento ambiental da bacia do alto rio Coxim - MS. GEOUSP: Espaço e Tempo, v. 18, n. 1, p. 184-197, 2014.

CARVALHO, A. Distribuição geográfica e classificação botânica do gênero Coffea com referência especial à espécie Arábica. Boletins da Superintendência dos Serviços do Café, n. 226-230, p. 1-33, 1946.

COSTA NETO, J. F. et al. Cooperação técnico-científica entre o Instituto Nacional do Café (Inca) e o Centro de Investigação das Ferrugens do Cafeeiro (CIFC/ IICT). In: CARVALHO, M. L. S. (Eds.). Economia, sociologia e desenvolvimento rural: actas do $1^{\circ}$ Encontro Luso-Angolano. Évora: Comissão Executiva do $1^{\circ}$ Encontro Luso-Angolano em Economia, Sociologia e Desenvolvimento Rural, 2008. p. 105-124. 
COSTE, R. Coffee: the plant and the product. London: MacMillan, 1992.

DINIZ, A. C. Angola: o meio físico e potencialidades agrícolas. Lisboa: Instituto para a Cooperação Económica, 1973.

FARR, T. G.; KOBRICK, M. Shuttle radar topography mission produces a wealth of data. EOS (Transactions, American Geophysical Union), v. 81, n. 48, p. 583-585, 2000.

FERRÃO, R. G. et al. Café Conilon: técnicas de produção com variedades melhoradas. Vitória: Incaper, 2007.

FOOD AND AGRICULTURAL ORGANIZATION (FAO). CROPWAT 8.0. 2015. Available at: <http://www. fao.org/nr/water/infores_databases_cropwat.html>. Access on: 27 Mar. 2015.

GONÇALVES JÚNIOR, A. C. et al. Produtividade do milho em resposta a adubação com NPK e Zn em Argissolo Vermelho-Amarelo Eutrófico e Latossolo Vermelho Eutroférrico. Ciência e Agrotecnologia, v. 31, n. 4, p. 1231-1236, 2007.

HIJMANS, R. J. et al. Very high resolution interpolated climate surfaces for global land areas. International Journal of Climatology, v. 25, n. 15, p. 1965-1978, 2005.

INSTITUTO NACIONAL DO CAFÉ (Inca). Plano estratégico de médio prazo 2013-2017. Luanda: Ministério da Agricultura de Angola, 2013.

INTERNATIONAL COFFEE ORGANIZATION (ICO). Statistics historical data. 2014. Available at: <http:// www.ico.org/pt/coffee storyp.asp? section=Sobre o caf\%E9\#sthash.xDOagQqJ.dpuf $>$. Access on: 22 Aug. 2014.

LUPPI, A. S. L. et al. Metodologia para classificação de zoneamento agroclimatológico. Revista Brasileira de Climatologia, v. 15, n. 1, p. 80-97, 2014.
MATIELlO, J. B. O café: do cultivo ao consumo. São Paulo: Globo, 1991.

ODUR, G. I. Rehabilitating the coffee sector in Angola. 2005. Available at: <http://www.new-ag.info/pdf/ Rehabilitating-the-coffee-sector-in-Angola.pdf $>$. Access on: 22 May 2015.

PEEL, M. C.; FINLAYSON, B. L.; McMAHON, T. A. Updated world map of the Köppen-Geiger climate classification. Hydrology and Earth System Sciences, v. 11, n. 5, p. 1633-1644, 2007.

PEREIRA, A. R.; CAMARGO, A. P.; CAMARGO, M. B. P. Agrometeorologia de cafezais no Brasil. Campinas: Instituto Agronômico, 2008.

POHLAN, H. A. J.; JANSSENS, M. J. J. Growth and production of coffee. In: VERHEYE, W. H. (Ed.). Soils, plant growth and crop production: vol. III. Oxford: EOLSS, 2010.

REIS, P. R. Café Arábica: do plantio à colheita. Lavras: Epamig, 2010.

RONCHI, C. P.; DaMATTA, F. M. Aspectos fisiológicos do café Conilon. In: FERRÃO, R. G. et al. (Eds.). Café Conilon. Vitória: Incaper, 2007. p. 95-119.

SEDIYAMA, G. C. et al. Zoneamento agroclimático do cafeeiro (Coffea arabica L.) para o estado de Minas Gerais. Revista Brasileira de Agrometeorologia, v. 9, n. 3, p. 501509, 2001.

VAN ZYL, J. J. The shuttle radar topography mission (SRTM): a breakthrough in remote sensing of topography. Acta Astronautica, v. 48, n. 5-12, p. 559-565, 2001.

VIANELLO, R. L.; ALVES, A. R. Meteorologia básica e aplicações. 2. ed. Viçosa: Ed. UFV, 2012.

WORLD METEOROLOGICAL ORGANIZATION (WMO). Country profile database portal. 2014. Available at: <https://www.wmo.int/cpdb/>. Access on: 09 Dec. 2014. 